\title{
Subunit Composition of Functional Nicotinic Receptors in Dopaminergic Neurons Investigated with Knock-Out Mice
}

\author{
Nicolas Champtiaux, ${ }^{1}$ Cecilia Gotti, ${ }^{2}$ Matilde Cordero-Erausquin, ${ }^{1}$ Denis J. David, ${ }^{3}$ Cédric Przybylski, ${ }^{3}$ Clément Léna, ${ }^{1}$ \\ Francesco Clementi, ${ }^{2}$ Milena Moretti, ${ }^{2}$ Francesco M. Rossi, ${ }^{1}$ Nicolas Le Novère, ${ }^{1}$ J. Michael McIntosh, ${ }^{4}$ \\ Alain M. Gardier, ${ }^{3}$ and Jean-Pierre Changeux ${ }^{1}$ \\ ${ }^{1}$ Laboratoire de Neurobiologie Moléculaire, Centre National de la Recherche Scientifique Unité de Recherche Associée 2182 "Récepteurs et Cognition," \\ Institut Pasteur, 75724 Paris Cedex 15, France, ${ }^{2}$ Consiglio Nazionale delle Ricerche, Institute of Neuroscience, Section of Cellular and Molecular \\ Pharmacology, Department of Medical Pharmacology and Center of Excellence on Neurodegenerative Diseases, University of Milan, 20129 Milan, Italy, \\ ${ }^{3}$ Laboratoire de Neuropharmacologie Equipe Associée-Ministere de l'Education Nationale de la Recherche et de la Technologie, Faculté de Pharmacie \\ Institut Fédératif de Recherche-Institut de Signalisation at Innovation Thérapeutique, Institut de Signalisation et d'Innovation Thérapeutique, Université \\ Paris-Sud, F92296 Châtenay-Malabry cedex, France, and ${ }^{4}$ Departments of Psychiatry and Biology, University of Utah, Salt Lake City, Utah 84112
}

Nicotinic acetylcholine receptors (nAChRs) expressed by dopaminergic (DA) neurons have long been considered as potential therapeutic targets for the treatment of several neuropsychiatric diseases, including nicotine and cocaine addiction or Parkinson's disease. However, DA neurons express mRNAs coding for most, if not all, neuronal nAChR subunits, and the subunit composition of functional nAChRs has been difficult to establish. Immunoprecipitation experiments performed on mouse striatal extracts allowed us to identify three main types of heteromeric nAChRs $\left(\alpha 4 \beta 2^{\star}, \alpha 6 \beta 2^{\star}\right.$, and $\left.\alpha 4 \alpha 6 \beta 2^{\star}\right)$ in DA terminal fields. The functional relevance of these subtypes was then examined by studying nicotine-induced DA release in striatal synaptosomes and recording ACh-elicited currents in DA neurons from $\alpha 4$, $\alpha 6, \alpha 4 \alpha 6$, and $\beta 2$ knock-out mice. Our results establish that $\alpha 6 \beta 2^{\star} \mathrm{nAChRs}$ are functional and sensitive to $\alpha$-conotoxin MII inhibition. These receptors are mainly located on DA terminals and consistently do not contribute to DA release induced by systemic nicotine administration, as evidenced by in vivo microdialysis. In contrast, (non $\alpha 6) \alpha 4 \beta 2^{\star} \mathrm{nAChRs} \mathrm{represent} \mathrm{the} \mathrm{majority} \mathrm{of} \mathrm{functional} \mathrm{hetero-}$ meric nAChRs on DA neuronal soma. Thus, whereas a combination of $\alpha 6 \beta 2^{\star}$ and $\alpha 4 \beta 2^{\star}$ nAChRs may mediate the endogenous cholinergic modulation of DA release at the terminal level, somato-dendritic (non $\alpha 6) \alpha 4 \beta 2^{\star}$ nAChRs most likely contribute to nicotine reinforcement.

Key words: dopamine; knock-out mice; mesencephalon; nicotinic acetylcholine receptors; striatum; $\alpha$-conotoxine MII

\section{Introduction}

The dopaminergic (DA) neurons of the ventral tegmental area (VTA) and substantia nigra pars compacta $(\mathrm{SNc})$ play a key role in natural and artificial reinforcement (Berridge and Robinson, 1998), motor coordination, motor associative learning, and habit formation (Gerdeman et al., 2003). In DA neurons, nicotinic ACh receptors (nAChRs) are abundantly expressed both at the somatic (SNc, VTA) and terminal [dorsal striatum, nucleus accumbens $(\mathrm{Nac})$ ] levels, in which they might play different physiological roles.

nAChRs located in the VTA are critically involved in nicotine

Received March 31, 2003; revised June 24, 2003; accepted July 7, 2003.

This work was supported by the Collège de France, the Association pour la Recherche sur le Cancer, the Association Française contre les Myopathies, European Economic Community contracts 097038 and 097038, and European Community (EC) project HPRNCT200200258. F.C. is supported by grants from the Italian Ministero dell'Istruziona, I'Universita e la Ricerca (2002052378), the Progetto Strategico Neuroscienze, the Italian Ministry of Health (ICS 030.3/RA 0048), and EC contract HPRN-CT-2002-00258. J.M.M. is supported by National Institutes of Health Grants MH53631 and GM48677. We thank Drs. M. Zoli, L. M. Marubio, and N. Mechawar for critical reading of this manuscript and Drs. M. De Biasi, A. L. Beaudet, and A. Orr-Urtreger for providing $\alpha 5-/-$ mice.

Correspondence should be addressed to Dr. Jean-Pierre Changeux, Laboratoire de Neurobiologie Moléculaire, Institut Pasteur, 25-28 rue du Dr Roux, 75015 Paris, France. E-mail: changeux@pasteur.fr.

Copyright $\odot 2003$ Society for Neuroscience $\quad$ 0270-6474/03/237820-10\$15.00/0 addiction. Indeed, in rats, intra-VTA infusions of nicotine increase DA concentration in the Nac (Nisell et al., 1994), an effect thought to mediate the reinforcing properties of most addictive drugs (Di Chiara and Imperato, 1988). Also, intra-VTA infusion of nicotinic antagonists blocks the effect of systemic nicotine injections on accumbal DA release (Nisell et al., 1994) and disrupt nicotine self-administration (Corrigall et al., 1994). Electrophysiological experiments demonstrate that nicotine is able to increase the firing rate of DA neurons both in vitro and in vivo (Grenhoff et al., 1986; Pidoplichko et al., 1997; Picciotto et al., 1998). Although actions on nAChRs located on GABAergic interneurons or glutamatergic terminals in the VTA, or on pedunculopontine neurons, have been proposed to contribute to these effects (Nomikos et al., 2000; Corrigall et al., 2001; Mansvelder et al., 2002), somato-dendritic nAChRs expressed by VTA DA neurons remain good candidates for the primary reinforcing action of nicotine.

The functional importance of nAChRs present on DA terminals should not be underestimated, however. In the striatum, endogenous ACh exerts a strong tonic control on action potential-dependent DA release through the activation of $\beta 2$ containing $\left(\beta 2^{\star}\right)$ presynaptic nAChRs (Zhou et al., 2001). Fur- 
thermore, intra-Nac nicotine injections produce sensitization to the locomotor stimulant effects of systemic nicotine (Kita et al., 1992), whereas intra-striatal infusion of nicotinic antagonists blocks the induction of behavioral sensitization to amphetamineinduced stereotypies (Karler et al., 1996). These findings suggest that $\mathrm{nAChRs}$ on DA terminals might play a role in the control of locomotor behavior and in the development of some long-lasting adaptations associated with drug abuse.

To date, 11 neuronal nAChR subunits have been cloned in mammals, 8 of which $(\alpha 3-7, \beta 2-4)$ are expressed in rat DA neurons (Le Novère et al., 1996; Charpantier et al., 1998; Klink et al., 2001). In vitro, $\alpha 7$ is known to form homopentameric nAChRs, whereas other subunits $(\alpha 2, \alpha 3, \alpha 4, \alpha 6, \beta 2$, and $\beta 4)$ associate to form heteropentamers with a $2 \alpha, 3 \beta$ stoichiometry (for review, see Role and Berg, 1996). The structural subunits $\alpha 5$ and $\beta 3$, so called because they lack critical residues necessary to form a ligand binding site, are incorporated into heteromeric nAChRs with at least one other $\alpha$ subunit and one other $\beta$ subunit (Ramirez-Latorre et al., 1996; Wang et al., 1996; GrootKormelink et al., 1998). In vivo, studies on $\beta 2$ knock-out (Ko) mice have demonstrated that functional heteromeric nAChRs expressed by DA neurons in the cell body or terminal regions contain the $\beta 2$ subunit (Picciotto et al., 1998; Grady et al., 2001, 2002). Recent immunoprecipitation (IPP) experiments have examined the nature of the $\alpha$ subunits associating with $\beta 2$ to form nAChRs on DA terminals in the rat striatum (Zoli et al., 2002).

We confirmed these results in mice and extended them using Ko mice for various nAChR subunits. Furthermore, we combined several experimental approaches ranging from electrophysiological recordings of DA neurons to in vivo microdialysis to establish the functionality and the relative abundance of the nAChR subtypes identified at the somatic and terminal level. Evidence is presented that the populations of nAChRs differ in these two compartments.

\section{Materials and Methods}

Mice. All animals were used in accordance with the Centre National de la Recherche Scientifique guidelines for care and use of laboratory animals. The generation of $\beta 2-/-, \alpha 4-/-$, and $\alpha 6-/-$ mice has been described previously (Picciotto et al., 1995; Marubio et al., 1999; Champtiaux et al., 2002). For microdialysis experiments, we used $\alpha 6-/-$ and $\alpha 6+/+$ littermates obtained by heterozygous matings (N4 backcross generation with C57Bl/6J mice; Charles River, Wilmington, MA). For other experiments, Ko and matching wild-type (Wt) control colonies were bred separately. For each colony, at least five couples of homozygous breeders were produced by mating heterozygous mice, obtained after $1(\alpha 6), 7$ $(\alpha 4)$, or $12(\beta 2)$ backcrosses with C57Bl/6J mice.

Reagents. Unless specified, all chemical reagents were purchased from Sigma (St. Louis, MO). $\alpha$-Conotoxin MII ( $\alpha$ CtxMII) was synthesized as described previously (Cartier et al., 1996).

Antibody production. Polyclonal antibodies (Abs) directed against nAChR subunits were produced in rabbit and affinity purified as described previously (Vailati et al., 1999). Peptides sequence was derived from the C-terminal $(\mathrm{COOH})$ or intracytoplasmic loop $(\mathrm{Cyt})$ regions of the rat $(\mathrm{R})$ or human $(\mathrm{H})$ subunit sequence: $\alpha 2(\mathrm{H}-\mathrm{Cyt})$, CHPLRLKLSPSYHWLESNVDAEEREV; $\alpha 3(\mathrm{H}-\mathrm{Cyt})$, TRPTSNEGNAQKPRPLYGAELSNLNC; $\alpha 4$ (H-Cyt), SPSDQLPPQQPLEAEKASPHPSPGP; $\alpha 4(\mathrm{R}-\mathrm{COOH})$, cgPPWLAGMI; $\alpha 5$ (R-Cyt), DRYFTQREEAESGAGPKSRNTLEAALDC; $\alpha 6$ (R-Cyt), GVKDPKTHTKRPAKVKFTHRKEPKLLKEC; $\beta 2$ (H-Cyt), RQREREGAGALFFREAPGADSC; $\beta 3(\mathrm{R}-\mathrm{COOH}), \mathrm{cgPALKM}-$ WIHRFH; $\beta 4$ (R-Cyt), VSSHTAGLPRDARLRSSGRFREDLQEALEGc. Lowercase letters are amino acids introduced to enable coupling to carrier protein. Underlined letters are mismatches with the mouse sequence.

$\mathrm{Ab}$ specificity and IPP efficiency was checked on tissue extracts from Wt and Ko mice as well as on affinity-purified nAChR subtypes (all the values reported below are the mean \pm SEM of three independent determinations). Anti- $\alpha 4,-\alpha 5,-\alpha 6$, and $-\beta 2$ Abs immunoprecipitated, respectively, $82 \pm 7 \%, 10 \pm 1 \%, 30 \pm 2 \%$, and $92 \pm 5 \%$ of ${ }^{3} \mathrm{H}$-Epibatidine (Epi)-labeled nAChRs in whole brain $(\alpha 4, \alpha 5, \beta 2)$ or striatal $(\alpha 6)$ extracts from $\mathrm{Wt}$ mice compared with $0,0,1.9 \pm 0.4 \%$, and $1.6 \pm 0.8 \%$ in the corresponding extracts from $\alpha 4, \alpha 5, \alpha 6$ and $\beta 2$ Ko controls. Anti- $\alpha 5$ and $-\alpha 6$ Abs immunoprecipitated, respectively, $75 \pm 7 \%$ of $\alpha 5^{\star}$ nAChRs (purified from cortex) and $75 \pm 3 \%$ of $\alpha 6^{*} \mathrm{nAChRs}$ (purified from retina). Anti- $\alpha 3$ and $-\beta 4$ Abs immunoprecipitated, respectively, $2.3 \pm$ $0.1 \%$ and $2.5 \pm 1 \%$ of ${ }^{3} \mathrm{H}$-Epi binding sites in striatal extracts compared with $74 \pm 3 \%$ and $68 \pm 2 \%$ in superior cervical ganglion (known to express $\alpha 3$ and $\beta 4$ mRNA) extracts. Anti- $\beta 3$ Abs immunoprecipitated $13 \pm 3 \%$ and $8 \pm 3 \%$ of ${ }^{3} \mathrm{H}$-Epi binding sites in superior colliculus and striatal extracts, respectively (projecting regions from retina and $\mathrm{SN}$ / VTA, where $\beta 3$ mRNA is expressed), but $\approx 0 \%$ of ${ }^{3} \mathrm{H}$-Epi binding sites in superior cervical ganglion extracts, where $\beta 3$ mRNA is not detected.

IPPs. Extract preparation and subsequent IPP were performed as described (Vailati et al., 1999). Briefly, the dissected tissue was homogenized in $50 \mathrm{~mm} \mathrm{Na}$ phosphate, pH 7.4, $1 \mathrm{~m} \mathrm{NaCl}, 2$ mм EDTA, 2 mм EGTA, and $2 \mathrm{~mm}$ PMSF using a potter homogenizer and centrifuged (1 $\mathrm{hr} ; 60,000 \times \mathrm{g}$ ). The pellet was collected; homogenized in $50 \mathrm{~mm}$ Tris$\mathrm{HCl}, \mathrm{pH}$ 7, $150 \mathrm{~mm} \mathrm{NaCl}, 5 \mathrm{~mm} \mathrm{KCl}, 1 \mathrm{~mm} \mathrm{MgCl}$, $2.5 \mathrm{~mm} \mathrm{CaCl}_{2}$, and 2 mM PMSF; centrifuged $(1 \mathrm{hr} ; 40,000 \times g)$; and then resuspended in the same buffer containing a mixture of $20 \mu \mathrm{g} / \mathrm{ml}$ of the leupeptin, bestatin, pepstatin $\mathrm{A}$, and aprotinin protease inhibitors. Membranes were solubilized by adding $2 \%$ Triton X-100 $\left(2 \mathrm{hr}, 4^{\circ} \mathrm{C}\right)$. After centrifugation $(1.5 \mathrm{hr}$; $60,000 \times g$ ) to remove nonsolubilized material, extracts were preincubated with $2 \mu \mathrm{M} \alpha$-bungarotoxin ( $\alpha$ Bgtx), labeled with $2 \mathrm{nM}{ }^{3} \mathrm{H}$-Epi (50-66Ci/mmole; Amersham, Arlington Heights, IL), and incubated (overnight, $0^{\circ} \mathrm{C}$ ) with a saturating concentration $(20-30 \mu \mathrm{g})$ of each subunit-specific $\mathrm{Ab}$ or preimmune IgG (to measure nonspecific IPP). IPP was induced by adding beads bound with goat anti-rabbit IgG.

To determine the subunit composition of $\alpha 6^{*} \mathrm{nAChRs}$, affinity columns were prepared with anti- $\alpha 6 \mathrm{Abs}(1 \mathrm{mg} / \mathrm{ml})$ bound to $\mathrm{CNBr}$ activated Sepharose4B (Amersham). Striatal extracts from $\alpha 6+/+$ animals (20-40 mice) were passed three times on the affinity column. The number of $\alpha 6^{*}$ nAChRs in the flow-through dropped to $2.5 \pm 0.8 \%$ of total nAChRs. Bound receptors were eluted by competition with the peptide $(100 \mu \mathrm{M})$ used for $\alpha 6 \mathrm{Ab}$ production. IPP was then performed as on crude striatal membrane extracts. The same procedure was used to determine the subunit content of $(\text { non } \alpha 6)^{*}$ nAChRs. In this case, the flow-through of the anti- $\alpha 6$ affinity column or crude striatal extracts from $\alpha 6-/-$ mice were loaded on an anti- $\alpha 4$ affinity column.

6-Hydroxydopamine lesions. Mice were anesthetized with chloral hydrate $(400 \mathrm{mg} / \mathrm{kg}$, i.p.) and received a bilateral stereotaxic injection $(4$ $\mu \mathrm{l} /$ side; $4 \mathrm{~min}$ ) of a solution containing $1 \times \mathrm{PBS}, 0.02 \%$ ascorbic acid, and 6-hydroxydopamine (6-OHDA) hydrochloride $(4 \mu \mathrm{g} / \mu \mathrm{l})$ in the dorsal striatum [Bregma coordinates (in $\mathrm{mm}$ ): anterior, 0.4 ; lateral, +2.0 ; ventral, 3.0] using a $10 \mu \mathrm{l}$ Hamilton syringe (26 gauge). Control animals received an injection of $1 \times$ PBS and $0.02 \%$ ascorbic acid. Extracts from dorsal striatum were prepared $7 \mathrm{~d}$ after lesion. The extent of DA denervation was assessed by ${ }^{3} \mathrm{H}$-WIN35,428 (NEN, Boston, MA) binding, a ligand for DA transporter (Zoli et al., 2002).

Ligand binding on immunoimmobilized $n A C h R s$. Subunit-specific Abs $(10 \mu \mathrm{g} / \mathrm{ml}$ ) were bound to microwells (Maxi-Sorp; Nunc, Roskilde, Denmark) by overnight incubation at $4^{\circ} \mathrm{C}$. After washing to remove unbound Abs, striatal extracts prepared from $\alpha 6+/+$ and $\alpha 4-/-$ mice, or from $\alpha 6-/-$ mice, were added to the wells prepared with anti- $\alpha 6$ or anti- $\beta 2$ Abs, respectively. After overnight incubation at $4^{\circ} \mathrm{C}$, the wells were washed, and binding experiments were performed as described (Vailati et al., 1999). For saturation experiments, ${ }^{125} \mathrm{I}$-Epi (2200Ci/mmole; NEN) was used at concentrations ranging from 0.005 to $2 \mathrm{~nm}$. For inhibition experiments, the immunoimmobilized receptors were incubated (30 min, room temperature) with various concentrations of unlabeled ligands before adding ${ }^{125} \mathrm{I}$-Epi at the $K_{\mathrm{d}}$ concentration. Incubation was prolonged overnight at $4^{\circ} \mathrm{C}$. Nonspecific binding was measured in the presence of $100 \mathrm{~nm}$ unlabeled Epi. For each ligand, data from three to six experiments were analyzed using the LIGAND program (Vailati et al., 1999). 
Synaptosomes. For each experiment, the striatum from one mouse was dissected on ice. Protocols for synaptosomes preparation, ${ }^{3} \mathrm{H}-\mathrm{DA}$ loading, and superfusion buffer (SB) composition were described previously (el-Bizri and Clarke, 1994). The superfusion apparatus comprised 20 identical channels consisting of a length of Tygon (1.14 mm inner diameter) and Teflon tubing ( $0.9 \mathrm{~mm}$; Polylabo, Strasbourg, France) leading to and from a polypropylene superfusion chamber. Synaptosome samples immobilized on GFA/E glass fiber filters (Gelman Science, Ann Arbor, MI) were perfused with $\mathrm{SB}\left(37^{\circ} \mathrm{C} ; 0.5 \mathrm{ml} / \mathrm{min}\right)$. After a $15 \mathrm{~min}$ washout period, samples were collected for $7 \mathrm{~min}$ before and $8 \mathrm{~min}$ after agonist application, at $1 \mathrm{~min}$ intervals. Antagonists, when tested, were present in SB throughout the experiment. Basal ${ }^{3} \mathrm{H}-\mathrm{DA}$ release was calculated as a single exponential decay from the seven fractions collected before agonist application. Peak ${ }^{3} \mathrm{H}-\mathrm{DA}$ release was calculated as the maximum of ( ${ }^{3} \mathrm{H}-\mathrm{DA}$ released-baseline)/baseline from the first three fractions collected after agonist application. For a particular condition (mouse genotype, agonist concentration, antagonist), peak release value was determined as the average of at least three independent triplicate experiments. For $\mathrm{EC}_{50}$ and Hill coefficient determination, peak release values were determined for different nicotine concentrations and normalized to the peak release value obtained with $3 \mu \mathrm{m}$ nicotine (measured in parallel). Normalized dose-response curves were fitted to the Hill equation [Release $=R_{\max } /\left(1+\left(\mathrm{EC}_{50} /[\mathrm{Nic}]\right)^{\mathrm{n}}\right)$, where $R_{\max }$ is maximum release, [Nic] is nicotine concentration, and $\mathrm{n}$ is the Hill coefficient] using SigmaPlot 4.16 (Jandel Scientific, San Rafael, CA).

Electrophysiological recordings of DA neurons. Eleven to 14-d-old mice were sacrificed by decapitation. The brain was removed rapidly and placed in ice-cold oxygenated Krebs solution containing (in mM) 126 $\mathrm{NaCl}, 2.5 \mathrm{KCl}, 1 \mathrm{MgCl} 2,2 \mathrm{CaCl} 2,1.25 \mathrm{NaH}_{2} \mathrm{PO}_{4}, 26 \mathrm{NaHCO}$, and 25 D-glucose. Coronal slices $(250 \mu \mathrm{m})$ were obtained using a DSK-1000 slicer (Dosaka, Kyoto, Japan) and were left at least $1 \mathrm{hr}$ to recover at room temperature. A single slice was transferred to the recording chamber superfused with oxygenated Krebs at $35 \pm 0.5^{\circ} \mathrm{C}$, at a rate of $1.8 \mathrm{ml} / \mathrm{min}$. Atropine $(1 \mu \mathrm{M})$ was added to the Krebs solution to inhibit muscarinic receptors. Whole-cell recordings were obtained from SNc/VTA neurons identified using infrared videomicroscopy with Nomarksy optics. Only presumptive projection neurons of large and medium size were targeted; presumptive interneurons of small size were avoided. Patch pipettes were filled with the following (in $\mathrm{mm}$ ): $144 \mathrm{~K}$-gluconate, $3 \mathrm{MgCl} 2$, $0.2 \mathrm{EGTA}$, and 10 HEPES, pH 7.2, yielding a 2-4 M $\Omega$ resistance. Recordings were performed with an Axopatch-1C (Axon Instruments, Foster City, CA) amplifier operating under current-clamp or voltage-clamp mode, filtered at $1 \mathrm{kHz}$, acquired at $3.33 \mathrm{kHz}$, and analyzed using PClamp 8 (Axon Instruments). DA neurons where selected according to the long duration of their action potentials $(>2.4 \mathrm{msec})$ and long after hyperpolarization (Grace and Onn, 1989; Klink et al., 2001). Fast application of ACh (1 mM) was achieved by pressure-pulse delivery (30 psi during $30 \mathrm{msec}$ ) to a pipette positioned at $\approx 30 \mu \mathrm{m}$ from the targeted cell. One pulse was delivered every $2 \mathrm{~min}$. For each neuron, a control response was determined as the average of three consecutive responses to ACh application. Only neurons exhibiting a stable response were then bath perfused with the nicotinic antagonists $\alpha$ CtxMII (100 nM) and/or methyllycaconitine (MLA; $1 \mathrm{~nm}$ ). ACh pulses were administered 6, 8, and 10 min after the onset of antagonist perfusion. The antagonized response is the mean of these three responses. As observed previously in rat DA neurons (Klink et al., 2001), the effect of these nicotinic antagonists on Ach-induced currents recorded from SNc or VTA neurons were similar. Data collected from both cell types were pooled in the analysis.

In vivo microdialysis in freely moving mice. Microdialysis and DA measurements were adapted from (Malagié et al., 2001). Mice (9-12 weeks of age; $25-30 \mathrm{gm}$ ) were anesthetized with chloral hydrate ( $400 \mathrm{mg} / \mathrm{kg}$, i.p.), and a concentric microdialysis probe (cuprophan fibers; outer diameter, $0.30 \mathrm{~mm}$; active length, $2.0 \mathrm{~mm}$ ) was implanted into the ventral striatum [Bregma coordinates (in $\mathrm{mm}$ ): anterior, 0; lateral, +2.0 ; ventral, 4.5). This site was chosen after testing several rostrocaudal levels of the ventral striatum because it gave the highest and most consistent $\mathrm{DA}$ responses to a systemic nicotine injection in $\mathrm{C} 57 \mathrm{Bl} / 6 \mathrm{~J}$ mice. After a $\approx 20 \mathrm{hr}$ surgery recovery period, the probe was perfused continuously $(1.3 \mu \mathrm{l} / \mathrm{min})$ with artificial CSF (Malagié et al., 2001). DA content of dialysate samples collected every 15 min was measured using a HPLC analytical method (Malagié et al., 2001). The limit of sensitivity for DA was $\sim 0.5 \mathrm{fmol}$ per sample (signal-to-noise ratio $=2$ ). Basal DA values were measured on the five to eight fractions collected before intraperitoneal nicotine injection $(0,0.5$, or $1.0 \mathrm{mg} / \mathrm{kg}$ in $0.9 \% \mathrm{NaCl} ; 10 \mu \mathrm{l} / \mathrm{g})$. Responses to drug administration were determined over a $120 \mathrm{~min}$ period. At the end of the experiment, the placement of the microdialysis probes was verified histologically.

\section{Results}

\section{$\alpha 4, \alpha 6$, and $\beta 2$ are the most abundant $\mathrm{nAChR}$ subunits in mice striatum}

To determine the subunit composition of heteromeric nAChRs in DA terminal fields, we performed IPP on mouse striatal membrane extracts. For each subunit, we raised a polyclonal $\mathrm{Ab}$ against a peptide chosen to minimize intersubunit crossreactivity. Ab specificity and IPP efficiency were tested on tissue extracts from Wt and $\alpha 4, \alpha 5, \alpha 6$, and $\beta 2$ Ko mice (see Materials and Methods). Before IPP, incubation of the solubilized extracts with $2 \mathrm{nM}{ }^{3} \mathrm{H}$-Epi, a highly specific nicotinic ligand, ensured that only nAChRs were quantified by radioactive counting of the immunoprecipitated material. A preincubation step with $2 \mu \mathrm{M}$ unlabeled $\alpha$ Bgtx prevented the binding of ${ }^{3} \mathrm{H}$-Epi to homomeric $\alpha 7$ nAChRs.

In $\alpha 6+/+$ mice (Fig. $1 A$ ), the vast majority (97\%) of striatal Epi binding sites could be immunoprecipitated using the anti- $\beta 2$ Ab. High levels of $\alpha 4^{*}(67 \%)$ and $\alpha 6^{*}(30 \%)$ nAChRs were also detected. In contrast, the contribution of $\alpha 2$ (3\%), $\alpha 3$ (2\%), and $\beta 4(2 \%)$ subunits to striatal Epi binding sites was minimal. Finally, a small fraction of heteromeric nAChRs contained the structural subunits $\alpha 5(12 \%)$ and $\beta 3(8 \%)$. Similar results have been obtained using striatal extracts from $\alpha 4+/+$ mice (Fig. $1 B$ ) and from rat (Zoli et al., 2002).

Because only a portion of striatal nAChRs are located on DA terminals (Clarke and Pert, 1985), we performed a selective denervation of DA terminals using 6-OHDA. In DA denervated dorsal striatum of $\alpha 6+/+$ mice (Fig. 1C), we observed a $90 \%$ reduction of $\alpha 6^{\star}$ and $\beta 3^{\star}$ nAChRs. The number of $\alpha 4^{\star}$ and $\beta 2^{\star}$ nAChRs was only reduced by $50 \%$, whereas the number of ${ }^{125} \mathrm{I}-$ $\alpha$ Bgtx binding sites was not affected by the lesion. These results indicate that striatal $\alpha 6^{*}$ and $\beta 3^{*}$ nAChRs are located on DA terminals (exclusively), whereas $\alpha 7^{\star}$ nAChRs are not. Striatal $\alpha 4^{\star}$ and $\beta 2^{*} \mathrm{nAChRs}$ are both expressed on DA terminals and non-DA cells or terminals.

IPP experiments were also conducted in $\alpha 4-/-$ and $\alpha 6-/-$ animals to check for the consequences of single subunit gene inactivation on the composition of striatal nAChRs. As reported previously (Champtiaux et al., 2002), we could not detect any significant decrease in total Epi binding in striatal extracts from $\alpha 6-/-$ compared with $\alpha 6+/+$ mice $(83.3 \pm 5.1$ and $89.4 \pm 4.6$ $\mathrm{fmol} / \mathrm{mg}$ of protein, respectively). This finding can be explained by the upregulation of $\alpha 4^{\star}$ nAChRs seen in $\alpha 6-/-$ animals (Fig. $1 A)$. In contrast, in $\alpha 4-/-$ animals, the total number of Epi binding sites was decreased by $86 \%$. Among the remaining Epi binding sites, $68 \%$ contained the $\alpha 6$ subunit and $81 \%$ the $\beta 2$ subunit (Fig. $1 B$ ). Interestingly, in $\alpha 4-/-$ animals, the number of $\alpha 6^{*}$ nAChRs was reduced by $57 \%$ compared with $\alpha 4+/+$ mice, suggesting the existence of $\alpha 4 \alpha 6^{\star} \mathrm{nAChRs}$ in Wt mice.

\section{Subunit composition of purified nAChRs. Existence of $\alpha 4 \alpha 6 \beta 2^{\star}$ oligomers.}

To test this hypothesis, we looked at the subunit composition of $\alpha 6^{*}$ nAChRs purified from $\alpha 6+/+$ striatal extracts on an affinity 

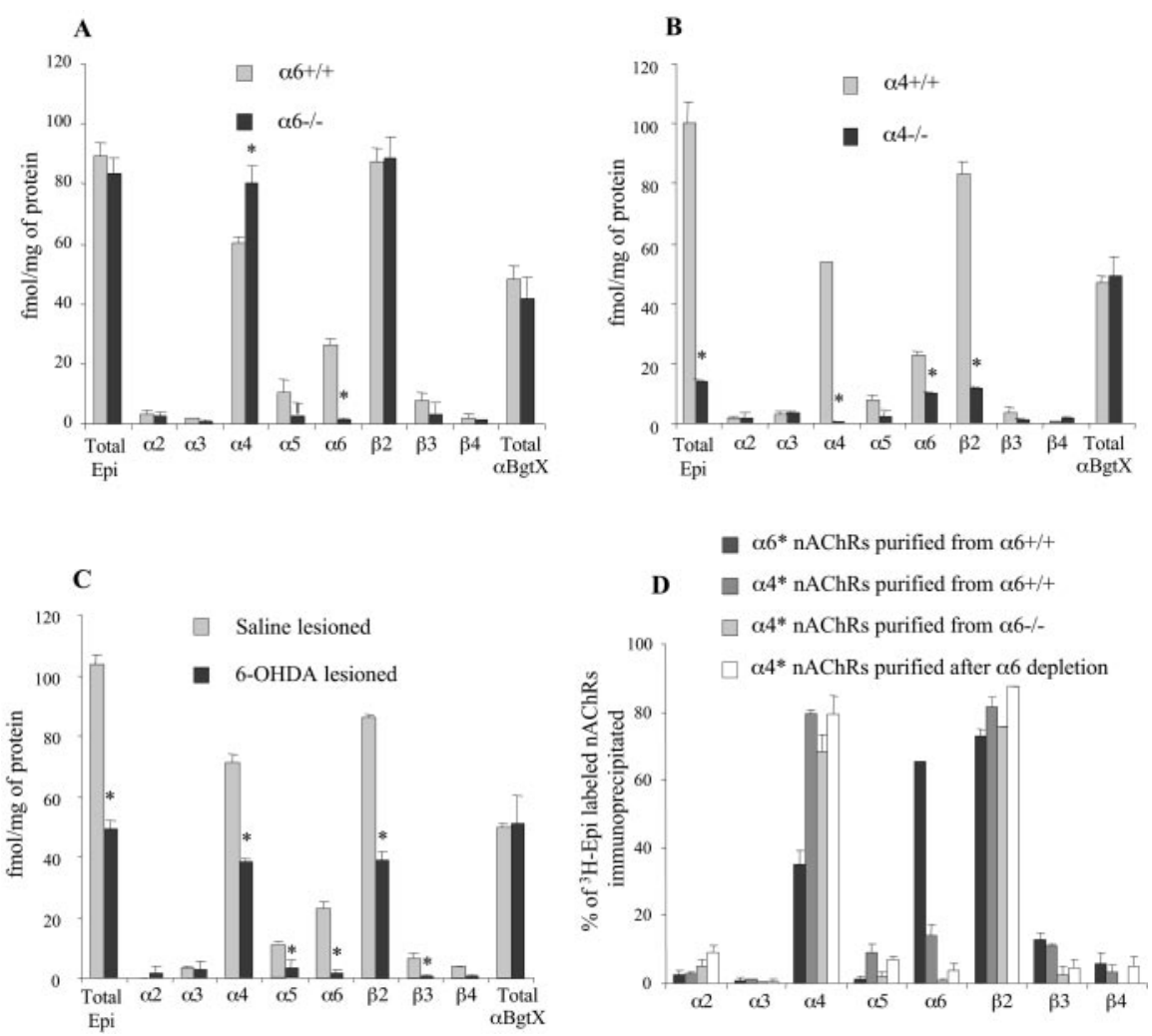

Figure 1. Subunit composition of striatal nAChRs. $A, B$, Solubilized striatal membrane extracts from $\alpha 6-/-, \alpha 4-/-$, $\alpha 6+/+$, and $\alpha 4+/+$ mice, preincubated with $2 \mathrm{~nm}^{3} \mathrm{H}$-Epi, were immunoprecipitated with subunit-specific Abs. Results are expressed in femtomoles of immunoprecipitated ${ }^{3} \mathrm{H}$-Epi/mg of protein $\left(n=3-5\right.$; $^{*} p<0.05$ compared with matching Wt control; Student's $t$ test). Total ${ }^{3} \mathrm{H}$-Epi and ${ }^{125} \mathrm{I}-\alpha \mathrm{BgtX}$ binding to striatal extracts is indicated. C, IPP experiments were conducted on extracts from the dorsal striatum of $\alpha 6+/+$ mice after $6-0 \mathrm{HDA}$ lesions. Each value is the mean of two to three independent determinations on different groups of animals ( ${ }^{*} p<0.05$ compared with saline-lesioned groups; Student's $t$ test). The extent of DA denervation was assessed by ${ }^{3} \mathrm{H}-\mathrm{WIN} 35,428$ binding, a ligand for DA transporter ( $204 \pm 26$ and $41 \pm 3 \mathrm{fmol} / \mathrm{mg}$ protein in the saline- and 6-OHDA-lesioned groups, respectively). $D, \alpha 6^{*}$ and $\alpha 4^{*} \mathrm{nAChRs}$ were purified from $\alpha 6+/+$ striatal extracts using an anti- $\alpha 6$ and an anti- $\alpha 4$ affinity column. (non $\alpha 6) \alpha 4^{*}$ nAChRs were purified on an anti- $\alpha 4$ affinity column using striatal extracts from $\alpha 6-/-$ mice or from $\alpha 6+/+$ mice after $\alpha 6$ depletion. The subunit content of purified nAChRs was determined by IPP. The amount of ${ }^{3} \mathrm{H}$-Epi immunoprecipitated is expressed as percentage of total ${ }^{3} \mathrm{H}$-Epi bound to the purified material before IPP $(n=3)$.

column bearing anti- $\alpha 6$ antibody. The proportion of $\alpha 6^{*}$ nAChRs in the flow-through of the affinity column dropped to $2.5 \pm 0.8 \%$ of total nAChRs, demonstrating the efficiency of the depletion. Purified nAChRs were then eluted from the column by an excess of the $\alpha 6$ peptide, and their subunit content was determined by IPP. Using this procedure, we found that a significant fraction of $\alpha 6^{*}$ nAChRs also contain the $\alpha 4$ (35\%) and/or the $\beta 3$ $(13 \%)$ subunits (Fig. 1D). The specificity of the purification was confirmed on $\alpha 6-/-$ striatal extracts (yielding only $2 \%$ of the number of Epi binding sites obtained using a similar amount of $\alpha 6+/+$ striatal tissue).

A similar procedure, using an anti- $\alpha 4$ affinity column, allowed us to purify $\alpha 4^{*}$ nAChRs from $\alpha 6+/+$ striatal extracts and confirmed the presence of the $\alpha 6$ subunit in $14 \%$ of $\alpha 4^{*}$ purified nAChRs. The structural subunits $\alpha 5$ and $\beta 3$ were also found in $9 \%$ and $11 \%$ of $\alpha 4$-purified receptors, respectively.

At last, purification of $\alpha 4^{*}$ nAChRs from $\alpha 6+/+$ striatal extracts after $\alpha 6$ depletion or from $\alpha 6-/-$ striatal extracts revealed that (non $\alpha 6) \alpha 4^{\star}$ nAChRs were essentially composed of the $\alpha 4$ and $\beta 2$ subunits [most likely $(\alpha 4)_{2}(\beta 2)_{3}$ ].

\section{Pharmacological characterization of} immunoimmobilized receptors.

Having determined the composition of the major nAChR subtypes expressed in the mouse striatum, we studied their pharmacology after immunoimmobilization using anti- $\alpha 6$ and anti- $\beta 2$ Abs. $\beta 2$-Immunoimmobilized nAChRs from $\alpha 6-/-$ animals (mainly $\alpha 4 \beta 2$, according to our IPP experiments and, thus, referred to as " $\alpha 4 \beta 2$ " nAChRs for clarity), $\alpha 6$-immunoimmobilized nAChRs from $\alpha 4-/-$ animals (mainly $\alpha 6 \beta 2$, referred to as " $\alpha 6 \beta 2$ "), and $\alpha 6-$ immunoimmobilized nAChRs from $\alpha 6+/+$ animals (containing a mix of $\alpha 6 \beta 2$ and $\alpha 4 \alpha 6 \beta 2 \mathrm{nAChRs}$ ) were studied. Affinity for ${ }^{125}$ I-Epi was determined by saturation experiments, whereas displacement of ${ }^{125}$ I-Epi binding to immunoimmobilized receptors was used to determine $K_{\mathrm{i}}$ values for nicotinic agonists(cytisine, Ach, and nicotine) or antagonists (dtubocurarine, dihydro- $\beta$-erythroidine, $\alpha$ CtxMII, MLA) (Fig. 2, Table 1).

For the agonists, cytisine exhibited a higher affinity for $\alpha 4 \beta 2 \mathrm{nAChRs}$ than for $\alpha 6 \beta 2$ nAChRs. For the antagonists, $\alpha$ CtxMII and MLA both showed a high affinity for $\alpha 6 \beta 2 \mathrm{nAChRs}$ (1.07 nM and 231 nM, respectively) and a low affinity for $\alpha 4 \beta 2 \mathrm{nAChRs}$ ( $>10 \mu \mathrm{M}$ and $14.3 \mu \mathrm{M}$, respectively). In $\alpha 6$-immunoimmobilized nAChRs from $\alpha 6+/+$ mice, ${ }^{125}$ I-Epi displacement by $\alpha$ CtxMII and MLA was biphasic $(p<0.01$ compared with a monophasic model), suggesting the existence of a heterogenous population of sites. The estimated proportion of lowaffinity sites was $28 \pm 4 \%$ for $\alpha \mathrm{CtxMII}$ and $40 \pm 11 \%$ for MLA. For both ligands, the estimated $K_{\mathrm{i}}$ value for the low- and highaffinity binding sites were in good agreement with those obtained on $\alpha 4 \beta 2$ and $\alpha 6 \beta 2$ receptors, respectively (Table 1) (Mogg et al., 2002). Our interpretation of these results is that, in a fraction of $\alpha 6^{*}$ nAChRs, one of the two Epi binding sites (located at the interface between the $\alpha$ and $\beta$ subunits) is made up of an $\alpha 4 \beta 2$ interface with low affinity for $\alpha$ CtxMII and MLA. Control experiments on $\alpha 6-/-$ animals rule out the possibility of a nonselective immunoimmobilization of $(\text { non } \alpha 6)^{\star}$ nAChRs by our anti- $\alpha 6 \mathrm{Ab}$ (data not shown). These findings correlate well with IPP results showing that $\alpha 4 \alpha 6 \beta 2^{*}$ $\mathrm{nAChRs}$ are present in the striatum of Wt mice.

In striatal synaptosomes, $\alpha 6 \beta 2^{\star}$ and $\alpha 4($ non $\alpha 6) \beta 2^{\star}$ nAChRs each contribute $50 \%$ of the effect of nicotine on DA release The three main heteromeric $\mathrm{nAChR}$ subtypes found in striatum are $\alpha 4 \beta 2, \alpha 6 \beta 2$, and $\alpha 4 \alpha 6 \beta 2$. However, whereas $\alpha 6^{*} \mathrm{nAChRs}$ are mainly located on DA terminals, a significant proportion of striatal $\alpha 4 \beta 2^{\star}$ nAChRs is not present on DA terminals (Fig. 1C). To more directly evaluate the relative contributions of $\alpha 4^{*}$ and $\alpha 6^{*} \mathrm{nAChRs}$ to DA function at the terminal level, we studied nicotine-stimulated DA release in striatal synaptosomes.

Synaptosomes loaded with ${ }^{3} \mathrm{H}-\mathrm{DA}$ and immobilized on glass 
A

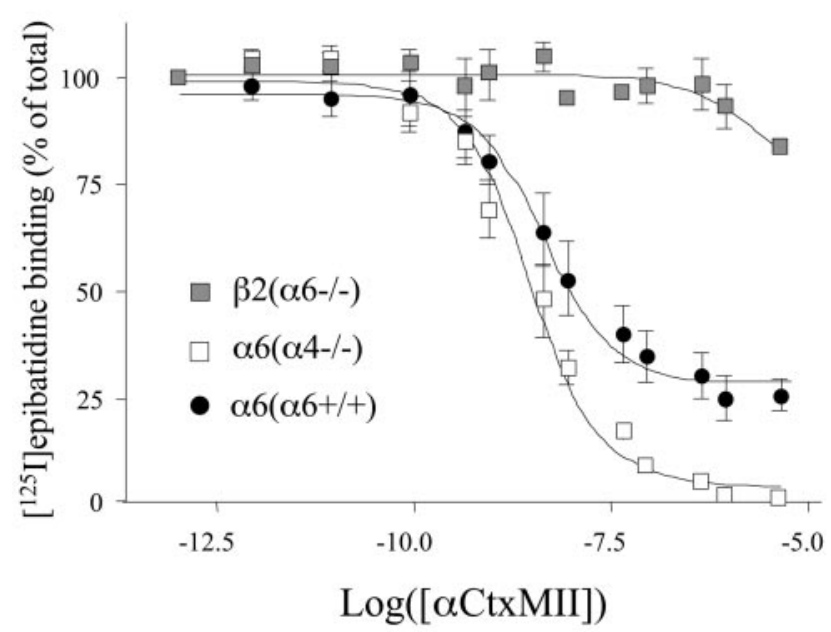

B

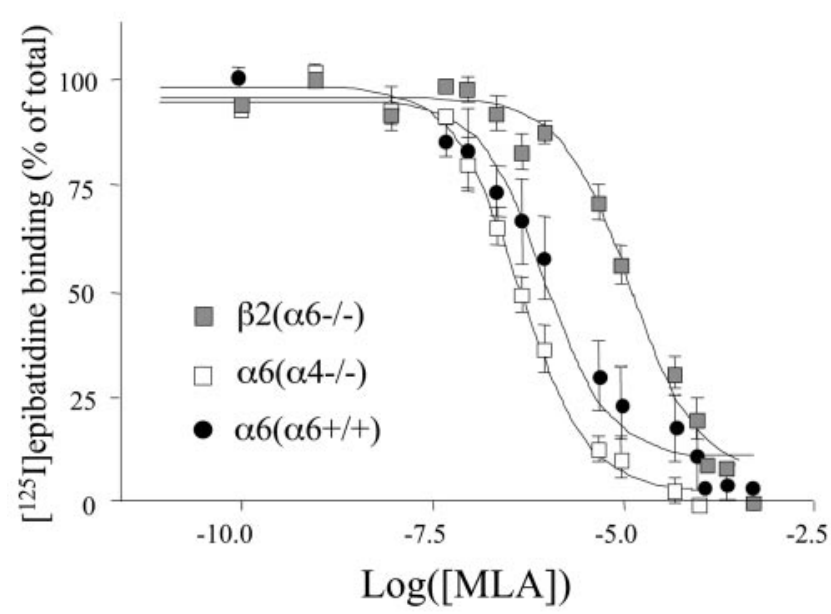

Figure 2. Displacement of $\left[{ }^{125} \mathrm{I}\right]$ epibatidine binding to immunoimmobilized nAChRs. $\alpha \operatorname{CtxMII}(A)$ and MLA $(B)$ were used to displace ${ }^{125}$-Epi binding to immunoimmobilized striatal $\mathrm{nAChRs}$. Three types of $\mathrm{nAChR}$ preparation have been tested in these experiments: $\beta 2 \mathrm{immu}$ noimmobilized nAChRs from $\alpha 6-/-$ animals [ $\beta 2(\alpha 6-/-)$ ] and $\alpha 6$-immunoimmobilized nAChRs from $\alpha 4-/-[\alpha 6(\alpha 4-/-)]$ or $\alpha 6+/+[\alpha 6(\alpha 6+/+)]$ animals. According to our IPP experiments, these three preparations are likely to contain primarily $\alpha 4 \beta 2, \alpha 6 \beta 2$, and a mix of $\alpha 4 \alpha 6 \beta 2$ and $\alpha 6 \beta 2 \mathrm{nAChRs,} \mathrm{respectively.} \mathrm{Data} \mathrm{points} \mathrm{were} \mathrm{fitted} \mathrm{to} \mathrm{a} \mathrm{one-} \mathrm{or} \mathrm{two-site}$ model using the LIGAND program (see Table 1 for fitting parameter values). For both ligands, this analysis revealed the existence of a heterogeneous population of binding sites only in $\alpha 6$ immunoimmobilized nAChRs from Wt mice. This result is in agreement with the existence of $\alpha 4 \alpha 6 \beta 2$ nAChRs. Each point is the mean \pm SEM of at least four separate determinations.

fiber filters were perfused with a saline buffer (unless specified, synaptosomes were obtained from adult mice whole striatum). When applied on synaptosomal preparations from $\alpha 4+/+$ or $\alpha 6+/+$ mice, nicotine ( $3 \mu \mathrm{M}$ for maximal effect) stimulated DA release by $\sim 100 \%$ above baseline level (peak value) (Fig. $3 A$ ). This effect was entirely blocked by mecamylamine (mean inhibition, $94 \pm 3 \% ; n=6$ ) or by removing $\mathrm{Ca}^{2+}$ from perfusion buffer (mean inhibition, $92 \pm 4 \% ; n=3$ ). In addition, a mix of NMDA $(\mathrm{AP}-5,100 \mu \mathrm{M})$ and non-NMDA (CNQX, $10 \mu \mathrm{M})$ ionotropic glutamate receptor antagonists did not alter DA response to nicotine (104 $\pm 5 \%$ of control response determined in parallel using an antagonist-free buffer; $n=4)$, ruling out the possibility of an indirect action of nicotine via stimulation of glutamate release. The effect of $3 \mu \mathrm{M}$ nicotine on DA release was reduced by half in both $\alpha 4-/-$ and $\alpha 6-/-$ animals (compared with $\alpha 4+/+$ and
Table 1. Pharmacological profile of immunoimmobilized $n A C h R s$

\begin{tabular}{|c|c|c|c|}
\hline Main subtypes & $\begin{array}{l}\alpha 6(\alpha 6+/+) \\
\alpha 6 \beta 2, \alpha 4 \alpha 6 \beta 2\end{array}$ & $\begin{array}{l}\beta 2(\alpha 6-/-) \\
\alpha 4 \beta 2\end{array}$ & $\begin{array}{l}\alpha 6(\alpha 4-/-) \\
\alpha 6 \beta 2\end{array}$ \\
\hline \multicolumn{4}{|l|}{ Ligand } \\
\hline \multicolumn{4}{|l|}{$K_{\mathrm{d}}, \mathrm{pm}$} \\
\hline$\left[{ }^{125} \mid\right]$ Epibatidine & $46(20)$ & 75 (34) & $34(24)$ \\
\hline \multicolumn{4}{|l|}{$K_{\mathrm{i}}, \mathrm{nM}$} \\
\hline Cytisine & $0.8(19)$ & $0.2(14)$ & $1.3(21)$ \\
\hline Nicotine & $2.8(40)$ & $1.7(19)$ & $3.8(31)$ \\
\hline $\mathrm{ACh}$ & $16.6(23)$ & $9.6(23)$ & ND \\
\hline Dihydro- $\beta$-erythroidine & $611(21)$ & $341(20)$ & ND \\
\hline D-Tubocurarine & $5072(20)$ & $20980(31)$ & ND \\
\hline$\alpha$ CtxMII (high affinity) & $2.14(41)$ & & $1.07(34)$ \\
\hline$\alpha$ CtxMII (low affinity) & $>10000$ & $>10000$ & \\
\hline MLA (high affinity) & $123(87)$ & & $231(23)$ \\
\hline MLA (low affinity) & $21900(43)$ & $14300(27)$ & \\
\hline
\end{tabular}

The $K_{\mathrm{d}}$ and $K_{\mathrm{i}}$ values were derived from saturation and competition binding curves obtained on $\alpha 6$ immunoimmobilized striatal nAChRs from $\alpha 6+/+$ and $\alpha 4-/-$ animals [columns $\alpha 6(\alpha 6+/+)$ and $\alpha 6(\alpha 4-/-)$, respectively] and on the $\beta 2$-immunoimmobilized nAChRs from $\alpha 6-/-$ animals [ $\beta 2(\alpha 6-/-)$ ]. According to our IPP experiments, the main immunoimmobilized subtypes are indicated. Curves obtained from three to six separate experiments were fitted using a nonlinear least-squares analysis program and the $F$ test. For $\alpha \mathrm{CtxMIl}$ and MLA, data analysis revealed the existence of a low- and high-affinity binding site in $\alpha 6^{*} \mathrm{nAChRs}$ of Wt animals. Numbers in parentheses represent the coefficient of variation as a percentage.

$\alpha 6+/+$ animals, respectively) and completely abolished in $\alpha 4-/$ $-\alpha 6-/-$ or $\beta 2-/-$ animals (Fig. 3A). The effect of $\mathrm{KCl}(23 \mathrm{~mm}$ ) application on DA release was not altered by inactivation of any nAChR subunit (data not shown). These results demonstrate that all nAChRs mediating the effects of nicotine on synaptosomal DA release contain the $\beta 2$ subunit in association with either $\alpha 4$ or $\alpha 6$ or both subunits. As will be detailed in Discussion, a specific contribution of $\alpha 4 \alpha 6 \beta 2^{\star}$ nAChRs to the effect of nicotine in $\mathrm{Wt}$ mice is suggested by the fact that nicotine potency is decreased by eightfold as a consequence of $\alpha 4$ inactivation (Fig. $3 C$ ) but is unaffected by gene targeting of the $\alpha 6$ subunit (Fig. $3 B$ ).

Because $\alpha$ CtxMII appears highly selective for $\alpha 6 \beta 2^{*} \mathrm{nAChRs}$ in binding experiments (Table 1), we examined the effect of this toxin on nicotine-elicited DA release to determine the relative contribution of $\alpha 6 \beta 2^{\star}$ and (non $\left.\alpha 6\right) \alpha 4 \beta 2^{\star}$ nAChRs. As described previously (Kulak et al., 1997; Kaiser et al., 1998; Sharples et al., 2000), $\alpha$ CtxMII (100 nM) reduced the effect of $3 \mu \mathrm{M}$ nicotine on DA release by $50 \%$ in $\alpha 4+/+$ or $\alpha 6+/+$ mice whole striatum (Fig. 3A). The inhibitory effect of $\alpha$ CtxMII was identical on synaptosomal preparations from the dorsal or ventral part of the striatum (mean inhibition: $49 \pm 5 \%$ and $47 \pm 7 \%$, respectively; $n=3)$. Finally, $\alpha$ CtxMII completely blocked the effect of nicotine in $\alpha 4-/-$ animals but had no inhibitory effect in $\alpha 6-/-$ mice. Taken together, these data demonstrate that the $\alpha$ CtxMIIsensitive fraction of nicotine-induced DA release is mediated by $\alpha 6^{*}$ nAChRs and, thus, that $\alpha 6^{*}$ nAChRs and $\alpha 4$ (non $\left.\alpha 6\right)^{*}$ nAChRs each contribute to $50 \%$ of the effect of nicotine in $\mathrm{Wt}$ mice striatum, regardless of the anatomical region examined (dorsal or ventral part).

To more easily compare results obtained in synaptosomal experiments and those derived from the study of ACh-induced currents in DA neurons (see below), we also studied ACh-elicited DA release in striatal synaptosomes from young (postnatal days 11-14) $\alpha 6+/+$ animals. In these conditions, in the presence of atropine $(1 \mu \mathrm{M}), \alpha$ CtxMII blocked $53 \pm 4 \%$ of peak DA release elicited by ACh $(10 \mu \mathrm{M}$ for maximal effect) application $(n=4)$.

\section{Slow ACh-elicited currents in SNc/VTA DA neurons are mediated by $\alpha \mathbf{4} \beta 2^{\star}$ and $\alpha 6 \beta 2^{\star}$ nAChRs}

To expand the results on DA terminals to somato-dendritic nAChRs, we studied the electrophysiological response of DA 

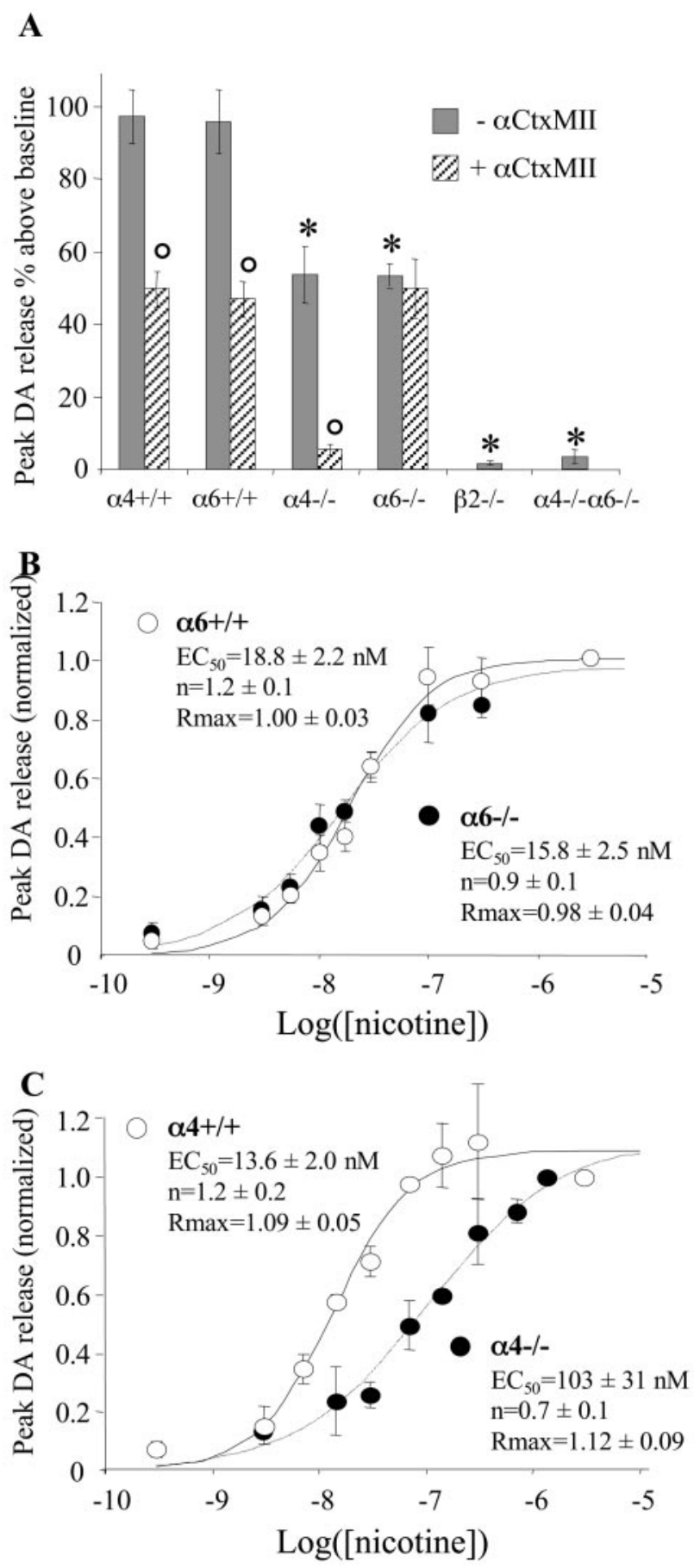

Figure 3. Nicotine-induced DA release in striatal synaptosomes. $A$, Striatal synaptosomes from $\alpha 4-/-, \alpha 6-/-, \beta 2-/-$, and $\alpha 4-/-\alpha 6-/-$ animals and their respective Wt controls were prepared and loaded with ${ }^{3} \mathrm{H}-\mathrm{DA}$. The effect of $3 \mu \mathrm{m} \mathrm{L}$-nicotine on DA release was determined in the presence or absence of $100 \mathrm{~nm} \alpha \mathrm{CtxMII}$. Peak ${ }^{3} \mathrm{H}-\mathrm{DA}$ release values (expressed as percentage of release above baseline levels) represent the mean \pm SEM of at least three determinations. ${ }^{*} p<0.01$ compared with matching Wt control (Student's $t$ test); ${ }^{\circ} p<$ 0.01 compared with $\alpha$ CtxMll-free condition (paired Student's $t$ test). B, C, Dose-response curves for nicotine-induced DA release. For each synaptosome preparation, data were normalized to the response obtained with $3 \mu \mathrm{m}$ nicotine. Dose-response curves were fitted to the Hill equation: Release $=R_{\max } /\left(1+\left(\mathrm{EC}_{50} /[\mathrm{Nic}]\right)^{n}\right)$.

neurons to ACh application. DA neurons in the SNc and VTA were identified according to their characteristic electrophysiological signature (see Materials and Methods). In Wt mice, in the presence of atropine to block muscarinic currents, fast ACh (1
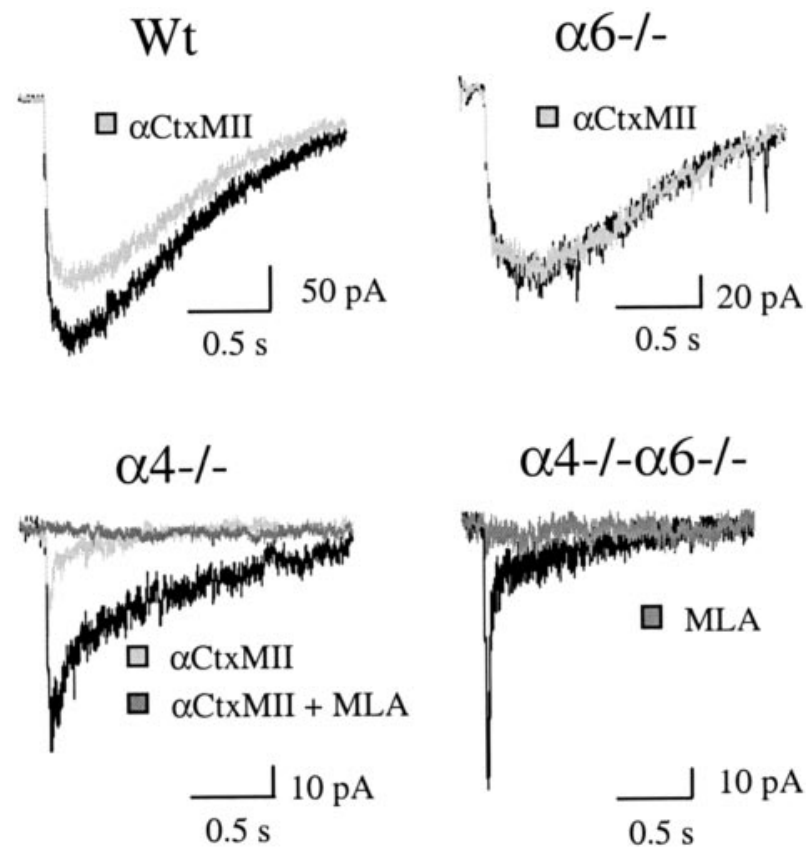

Figure 4. ACh-elicited currents in SNc/VTA DA neurons. Effect of $\alpha$ CtxMII. Representative traces of ACh-elicited currents in DA neurons from $\alpha 6+/+, \alpha 4-/-, \alpha 6-/-$, and $\alpha 4-/$ $-\alpha 6-/-$ mice. Mean $\alpha$ CtxMII (100 nm) inhibition values are shown in Table 2. In $\alpha 4-/$ $-\alpha 6-/-$ mice, or in $\alpha 4-/-$ animals after $\alpha$ CtxMll application, residual current exhibited the kinetic (fast rise and decay) and pharmacological characteristics (complete inhibition by 1 nм MLA) of $\alpha 7$ nAChR-mediated currents.

$\mathrm{mm}$ ) application elicited inward currents (Fig. 4) entirely blocked by mecamylamine ( $10 \mu \mathrm{M} ; n=2$; data not shown). Previous experiments on $\alpha 7-/-$ and $\beta 2-/-$ animals have demonstrated that both $\alpha 7$ homomeric and $\beta 2$ heteromeric nAChRs differentially contribute to this response (Klink et al., 2001). Whereas $\alpha 7$-mediated currents display fast activation and decay kinetics, $\beta 2^{*}$ nAChRs-mediated currents exhibit a slow activation and a long duration. The $\alpha$ partners of the $\beta 2$ subunit were investigated using $\alpha 4-/-, \alpha 6-/-$, and $\alpha 4-/-\alpha 6-/-$ mice (Table 2, Fig. 4).

The amplitude of ACh-elicited response is markedly decreased in $\alpha 4-/-$ animals. Residual currents in $\alpha 4-/-$ animals display faster activation kinetics than in $\mathrm{Wt}$ mice, but still exhibit a slow decay. This current waveform was never seen in $\beta 2-/-$ mice, suggesting that $\alpha 4 \beta 2^{*} \mathrm{nAChRs}$ are not the only $\beta 2^{*}$ nAChRs subtype contributing to the slow ACh-elicited current in Wt mice. To investigate whether $\alpha 6 \beta 2^{\star} \mathrm{nAChRs}$ could be involved, we studied the effect of $\alpha$ CtxMII (100 nM). In Wt mice, this toxin inhibited only a small fraction of ACh-gated currents (mean inhibition, $19 \pm 3 \% ; n=15 ; p<0.001$; paired Student's $t$ test), in agreement with the observation of a small (20\%), nonstatistically significant decrease of mean current amplitude in $\alpha 6-/-$ animals compared to their Wt controls. The specificity of $\alpha$ CtxMII for $\alpha 6^{*}$ nAChRs was checked in $\alpha 6-/-$ mice where it had no significant effect on ACh-elicited currents (mean inhibition, $6 \pm 5 \% ; n=7$ ). Two lines of evidence indicate that the modest inhibitory effect of $\alpha$ CtxMII seen in Wt mice is not because of partial efficacy or inadequate concentration of the antagonist. First, in $\alpha 4-/-$ animals, $\alpha$ CtxMII inhibited $64 \%$ of the ACh-elicited response. Second, the residual $\alpha$ CtxMII-resistant current exhibited all the kinetic (Table 2) and pharmacological characteristics (complete inhibition by 1 nм MLA; $n=4$ ) of $\alpha 7^{\star}$ homomeric nAChRs. In $\alpha 4-/-\alpha 6-/-$ animals in the absence 
Table 2. ACh-elicited current in DA neurons, waveform parameters, and effect of $\alpha$ CtxMII

\begin{tabular}{|c|c|c|c|c|c|}
\hline & $\begin{array}{l}\text { Wt } \\
(n=15)\end{array}$ & $\begin{array}{l}\alpha 6-/- \\
(n=7)\end{array}$ & $\begin{array}{l}\alpha 4-/- \\
(n=7)\end{array}$ & $\begin{array}{l}\alpha 4 \alpha 6-/- \\
(n=14)\end{array}$ & $\begin{array}{l}\alpha 4-/- \text { after } \alpha \text { CtxMII } \\
(n=4)\end{array}$ \\
\hline Amplitude (pA) & $202 \pm 24$ & $160 \pm 26$ & $107 \pm 18^{*}$ & $147 \pm 43$ & \\
\hline Rise time (msec) & $225 \pm 32$ & $189 \pm 39$ & $29 \pm 6^{* *}$ & $25 \pm 7^{* *}$ & $15 \pm 1$ \\
\hline Decay time (msec) & $>1000$ & $>1000$ & $496 \pm 148^{\circ}$ & $179 \pm 43$ & $162 \pm 43$ \\
\hline Half width (msec) & $647 \pm 97$ & $670 \pm 135$ & $87 \pm 28^{* * \circ}$ & $21 \pm 3^{* *}$ & $27 \pm 11$ \\
\hline$\alpha$ CtxMll inhibition (\%) & $19 \pm 3^{\dagger}$ & $6 \pm 5$ & $64 \pm 5^{\dagger}$ & & \\
\hline
\end{tabular}

Rise and decay time were measured between 10 and $90 \%$ of the peak value. Half-width is the time between $50 \%$ of the peak value on the rising phase and $50 \%$ of the peak value on the falling phase. In Wt and $\alpha 6-/-$ animals, decay time was not accurately measured because, in many cases, current did not come back to baseline levels before the end of the registering period (1.5 sec). In $\alpha 4-/-$ animals after $\alpha$ CtxMll inhibition, kinetic parameters were calculated only when the amplitude of residual current was sufficient to make a precise measure $(>40 \mathrm{pA}) .{ }^{*} p<0.05,{ }^{* *} p<0.01$ compared with Wt. ${ }^{\circ} p<0.05$ compared with $\alpha 4-/-\alpha 6-/-;$ Student's t test. $\alpha$ (txMIII inhibition is expressed as a percentage of basal response before antagonist application. Maximal amplitude and current kinetics were measured on three successive responses before and after ( $6 \mathrm{~min}) \alpha \mathrm{CtxMII}$ (100 $\mathrm{nm}$ ) bath perfusion. Because $\alpha \mathrm{CtxMll}$ inhibitory effect was small and irreversible (even after $10 \mathrm{~min}$ washout period), only neurons exhibiting a stable response to ACh application were kept in the analysis. ${ }^{\dagger} p<0.001$ compared with $\alpha$ CtxMll-free condition; paired Student's $t$ test.

of $\alpha$ CtxMII, the $\alpha 7^{\star}$ homomeric current was the only residual response observed $(n=14)$ and was entirely blocked by MLA $(n=3)$.

Altogether, these results demonstrate that both $\alpha 4$ and $\alpha 6$ subunits, in association with the $\beta 2$ subunit, form functional nAChRs that mediate the slow current component of AChelicited response in DA neurons from Wt animals.

\section{In vivo, $\alpha 6^{*} \mathrm{nAChRs}$ do not contribute to the effect of systemic nicotine injections on DA release}

As mentioned previously, the reinforcing properties of nicotine have been attributed to its ability to increase accumbal DA levels (for review, see Di Chiara, 2000). To examine the involvement of $\alpha 6^{*}$ nAChRs in this effect, we studied the consequences of systemic nicotine injection on DA levels in the ventral striatum of $\alpha 6-/-$ and $\alpha 6+/+$ mice. DA levels were monitored by in vivo microdialysis in freely moving mice. Basal extracellular DA levels in the ventral striatum did not differ between the two genotypes [12.6 \pm 0.6 and $13.4 \pm 0.5 \mathrm{fmol} / 20 \mu$ l of dialysate in $\alpha 6+/+(n=$ $11)$ and $\alpha 6-/-$ animals $(n=10)$, respectively]. After nicotine ( 0.5 or $1 \mathrm{mg} / \mathrm{kg}$; free base), but not after saline injection, an increase in striatal DA levels was observed in $\alpha 6+/+$ and $\alpha 6-/-$ animals (Fig. $5 A-C$ ). When plotting DA outflow (in percentage of basal levels) as a function of time, one can measure the area under the curve (AUC), which is an estimate of DA release over the 120 min post-treatment period (Fig. 5D). A two-way ANOVA on AUC values was performed, with drug treatment (saline, 0.5 or $1 \mathrm{mg} / \mathrm{kg}$ nicotine) and mouse genotype $(\alpha 6+/+$ or $\alpha 6-/-)$ as main factors. This statistical analysis revealed a significant treatment factor $\left(F_{(2,30)}=8.35 ; p<0.001\right)$, no significant genotype factor $\left(F_{(1,30)}=0.016 ; p=0.872\right)$, and no significant genotypetreatment interaction $\left(F_{(2,30)}=0.311 ; p=0.73\right)$.

These results demonstrate that in the range of doses tested, the effect of systemic nicotine injections on DA release in the ventral striatum is not mediated by $\alpha 6^{*} \mathrm{nAChRs}$. However, in view of the upregulation of $\alpha 4^{\star}$ Epi binding sites in the striatum of $\alpha 6-/-$ mice, one could argue that the lack of influence of the $\alpha 6$ mutation on nicotine-induced DA release is because of functional compensation. Although we cannot rule out this hypothesis, such compensation was not seen in efflux experiments. Indeed, in striatal synaptosomes from $\alpha 6-/-$ mice, the effect of nicotine on DA release was reduced by $50 \%$ compared with $\alpha 6+/+$ mice, a decrease closely corresponding to the $\alpha$ CtxMII-sensitive fraction of nicotine effect in Wt mice (Fig. 3A).

\section{Discussion}

In this article, we have established that the main heteromeric nAChR subtypes expressed by DA neurons contain the $\alpha 4$ and/or the $\alpha 6$ subunits in association with the $\beta 2$ subunit. IPP experiments on striatal extracts demonstrate that the most abundant
A

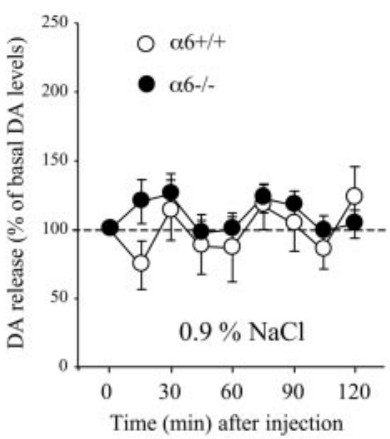

C

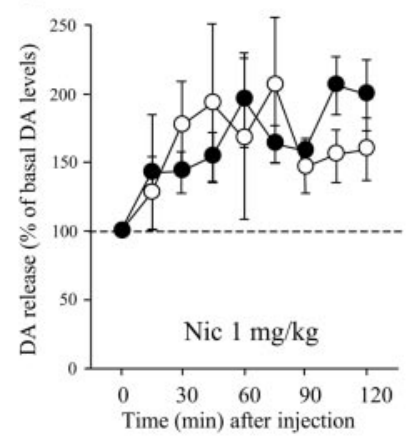

Figure 5. Nicotine-elicited DA release in the ventral striatum of $\alpha 6-/-$ mice. $A-C$, Mice ( $n=4-7$ animals per group) were injected intraperitoneally with a solution of 0.5 or $1 \mathrm{mg}$ $\mathrm{kg}^{-1}$ nicotine (free base), and extracellular DA levels were measured by microdialysis in the ventral striatum. Results are expressed as percentage of basal DA levels (mean of 5-8 samples collected immediately before treatment). Basal DA levels in perfusate did not differ between the two genotypes. $D$, AUC values, representing the amount of DA outflow collected during the $0-120$ min post-treatment period, are expressed as percentage of basal values. $\left({ }^{*} p<0.05\right.$ and ${ }^{* *} p<0.01$ relative to the corresponding control Na(l-treated group; two-way ANOVA). № statistically significant difference between $\alpha 6+/+$ and $\alpha 6-/-$ mice is observed.

subunits accounting for the majority of high-affinity ${ }^{3} \mathrm{H}$-Epi binding sites in DA terminal fields are the $\alpha 4, \alpha 6$, and $\beta 2$ subunits. Studying nicotine-elicited DA release in striatal synaptosomes or recording ACh-elicited currents on DA neurons further establishes the existence of two types of functional heteromeric nAChRs in DA neurons. In both types of experiments, the response to nicotinic agonists includes an $\alpha$ CtxMII-sensitive fraction, mediated by $\alpha 6 \beta 2^{*}$ nAChRs and an $\alpha$ CtxMII-resistant fraction attributed to $\alpha 4$ (non $\alpha 6) \beta 2^{\star}$ nAChRs. The partial inhibitory effect of $\alpha$ CtxMII on nicotine-induced DA release had already been observed but was initially attributed to the presence of $\alpha 3 \beta 2^{\star}$ nAChRs on DA terminals (Kulak et al., 1997; Kaiser et al., 1998; Sharples et al., 2000). Indeed, in Xenopus oocytes, $\alpha$ CtxMII was reported as selective for $\alpha 3 \beta 2^{\star}$ nAChRs (Cartier et al., 1996). 
We found little evidence for the presence of $\alpha 3^{\star}$ nAChRs in the striatum, confirming previous in situ hybridization results showing a very low concentration of $\alpha 3$ mRNA in DA neurons (Le Novère et al., 1996). IPP experiments showed that at the terminal level only $2 \%$ of ${ }^{3} \mathrm{H}$-Epi binding sites contain the $\alpha 3$ subunit. Moreover, in $\alpha 6-/-$ animals, the inhibitory effect of $\alpha$ CtxMII on nicotine-induced DA release or on ACh-elicited currents is entirely abolished. These results are in good agreement with the recent observations that high-affinity ${ }^{125} \mathrm{I}$ - $\alpha$ CtxMII binding sites are preserved in the striatum of $\alpha 3-/-$ animals (Whiteaker et al., 2002) but completely disappear in $\alpha 6-/-$ animals (Champtiaux et al., 2002). Ultimately, experiments on $\alpha 4-/-\alpha 6-/-$ double mutant mice establish that the $\alpha 4$ and $\alpha 6$ subunits are necessary constituents of all functional heteromeric nAChRs in DA neurons.

In addition to the simple $\alpha 6 \beta 2$ and $\alpha 4 \beta 2$ combinations, our experiments reveal the existence of an $\alpha 4 \alpha 6 \beta 2$ subtype in DA neurons. This was initially suggested by the decrease of $\alpha 6^{*}$ Epi binding sites in the striatum of $\alpha 4-/-$ animals (Fig. $1 B$ ) and was further confirmed by IPP performed on purified $\alpha 6^{\star}$ nAChRs. With this approach, we found that 35\% of $\alpha 6^{\star}$ nAChRs also contain the $\alpha 4$ subunit. We also found that $28 \%$ of ${ }^{125}$ I-Epi binding sites on $\alpha 6$ immunoimmobilized receptors (from Wt animals) were resistant to $\alpha$ CtxMII displacement, most likely reflecting the existence of an $\alpha 4 \beta 2$ interface in $\alpha 6^{*}$ nAChRs. Functionally, $\alpha 4 \alpha 6 \beta 2^{\star} \mathrm{nAChRs}$ were difficult to distinguish from $\alpha 6 \beta 2^{\star}$ nAChRs, because $\alpha$ CtxMII is likely to block both subtypes. Nonetheless, a clue as to the role of $\alpha 4 \alpha 6 \beta 2^{\star} \mathrm{nAChRs}$ is given by the study of DA release in synaptosomes. In this experiment, we found that the potency of nicotine is lower on $\alpha 6 \beta 2^{*}$ nAChRs, the only remaining $\mathrm{nAChR}$ subtype in the striatum of $\alpha 4-/-$ mice, than on $\alpha 4 \beta 2^{\star}$ nAChRs (Fig. 3, compare $\mathrm{EC}_{50}$ values in $\alpha 4-/-$ and $\alpha 6-/-$ animals). Accordingly, we found an eightfold increase in the $\mathrm{EC}_{50}$ value in $\alpha 4-/-$ animals compared with $\alpha 4+/+$ mice, revealing low potency $\alpha 6 \beta 2^{\star}$ nAChRs. However, we did not observe the expected corresponding decrease in the $\mathrm{EC}_{50}$ value in $\alpha 6-/-$ mice. Such a decrease would have been expected if $\alpha 6 \beta 2^{\star}$ and $\alpha 4 \beta 2^{\star}$ nAChRs each contributed to $50 \%$ of nicotine effect in Wt mice. These findings, in contrast, are compatible with a preponderant role of $\alpha 4 \alpha 6 \beta 2^{*}$ $\mathrm{nAChRs}$ in nicotine-mediated DA release in Wt mice because $\alpha 4 \alpha 6 \beta 2^{\star}$ and $\alpha 4 \beta 2^{\star} \mathrm{nAChRs}$ were shown to have a similar affinity for nicotine when expressed in Xenopus oocytes (Kuryatov et al., 2000). According to this hypothesis, the contribution of $\alpha 6 \beta 2$ $\mathrm{nAChRs}$ to nicotine-induced DA release, minimal in Wt mice, is only revealed in $\alpha 4-/-$ mice. Altogether, these results demonstrate the existence of $\alpha 4 \alpha 6 \beta 2^{\star}$ nAChRs in DA neurons and suggest a preponderant role of this subtype in mediating the $\alpha$ CtxMII-sensitive fraction of nicotine-elicited DA release.

Whereas the main heteromeric nAChRs subtypes identified in mouse DA neurons are constituted of the $\alpha 4 \beta 2, \alpha 6 \beta 2$, and $\alpha 4 \alpha 6 \beta 2$ combinations, a contribution of the structural subunits $\beta 3$ and $\alpha 5$ was also revealed. Interestingly, the $\alpha 5$ subunit was found preferentially associated with $\alpha 4^{\star} \mathrm{nAChRs}$ ( $\alpha 5$ was present in $9 \%$ of purified $\alpha 4^{\star}$ nAChRs compared with only $1 \%$ of $\alpha 6^{*}$ nAChRs; Fig. $1 D$ ), whereas the $\beta 3$ subunit was detected at similar levels in both $\alpha 6^{\star}$ and $\alpha 4^{\star}$ nAChRs ( $11 \%$ of purified $\alpha 4^{\star}$ and $13 \%$ of purified $\alpha 6^{\star}$ nAChRs also contained $\beta 3$ ). These results are in partial agreement with previous observations made in the rat striatum showing a preferential association of the $\alpha 5$ and $\beta 3$ subunits with $\alpha 4^{*}$ and $\alpha 6^{*}$ nAChRs, respectively (Zoli et al., 2002).

A main issue arising from the evidence of the diversity of
nAChRs in DA neurons is whether they are differentially expressed in different parts of DA pathways. So far, most studies have only revealed subtle differences in the subunit composition or pharmacology of nAChRs expressed in the mesolimbic or nigrostriatal DA pathways (Klink et al., 2001; Grady et al., 2002; Wooltorton et al., 2003). In the present study, $\alpha$ CtxMII was shown to inhibit nicotine-induced DA release to the same extent in synaptosomal preparations from the dorsal and ventral parts of the striatum, suggesting a similar proportion of $\alpha 6^{*}$ versus $\alpha 4(\text { non } \alpha 6)^{\star}$ nAChRs in both regions. Our data, however, reveal a heterogeneity in the nature of nAChRs mediating nicotinic agonists effects on DA neuron soma or terminals. Whereas $\alpha$ CtxMII can block $50 \%$ of the effect of nicotine on DA release in striatal synaptosomes, it has only a modest effect ( $<20 \%$ inhibition) on ACh-elicited currents in SN/VTA DA cell bodies. Moreover, ligand binding autoradiography experiments on mouse brain sections demonstrate that the ratio of ${ }^{125} \mathrm{I}-\alpha \mathrm{CtxMII}$ binding sites versus total ${ }^{3} \mathrm{H}$-Epi binding sites, taken as an estimate of the proportion of $\alpha 6^{*} \mathrm{nAChRs}$ within the total $\mathrm{nAChR}$ population, is more than three times higher in the Nac than in the VTA (M. Zoli, L. Marubio, N. Champtiaux, and J. P. Changeux, unpublished observations). Finally, IPP experiments show that $\alpha 6^{*}$ nAChRs account for $30 \%$ of ${ }^{3} \mathrm{H}$-Epi binding sites in the striatum (Fig. $1 A, B)$ but only $5 \%$ in SN/VTA (data not shown). Thus, $\alpha 6^{*}$ nAChRs appear to be preferentially addressed to DA nerve terminal compartment. In contrast, $\alpha 7^{\star} \mathrm{nAChRs}$ appear to be exclusively present on DA neuronal cell bodies. Indeed, although $\alpha 7$-mediated nicotinic currents could be detected at the somatic level, the lack of residual effect of nicotine on DA release in striatal synaptosomes from $\alpha 4-/-\alpha 6-/-$ or $\beta 2-/-$ mice, as well as the lack of effect of 6-OHDA lesions on ${ }^{125} \mathrm{I}-\alpha \mathrm{Bgtx}$ binding to striatal extracts, demonstrate the absence of $\alpha 7^{\star} \mathrm{nAChRs}$ on DA terminals (Kaiser and Wonnacott, 2000).

The mechanisms responsible for the differential targeting of the $\alpha 6^{\star}$ and $\alpha 7^{\star}$ nAChRs are unknown, but the paucity of $\alpha 6^{\star}$ nAChRs on DA neuron soma has important physiological implications. Indeed, it is known that activation of nAChRs located in the VTA, but not in the Nac, is critical for mediating DA release in the ventral striatum induced by systemic nicotine injections and maintaining nicotine self-administration (Corrigall et al., 1994; Nisell et al., 1994). In agreement with these observations, whereas the $\alpha 6$ subunit gene inactivation did not modify the effect of systemic nicotine on DA release in the ventral striatum, in $\alpha 4-/-$ animals, systemic nicotine injections $(0.5$ and $1 \mathrm{mg} / \mathrm{kg}$ ) failed to stimulate striatal DA outflow (Marubio et al., 2003). Thus, $\alpha 4^{*}$ rather than $\alpha 6^{*} \mathrm{nAChRs}$, presumably located in the VTA, are critical for nicotine reinforcement. In contrast, both $\alpha 4^{*}$ and $\alpha 6^{*}$ nAChRs are likely to contribute to the endogenous cholinergic modulation of DA release at the terminal level. In vitro, it was recently demonstrated that action potentialdependent DA release is under control of $\beta 2^{*} \mathrm{nAChRs}$ located on DA terminals and tonically activated by endogenous ACh (Zhou et al., 2001). The disruption of this control in $\beta 2-/-$ animals, leading to $80 \%$ decrease in electrically-evoked DA release, might explain the reduced sensitivity to the reinforcing effects of cocaine seen in $\beta 2-/-$ mice (Zachariou et al., 2001). In addition, the induction of behavioral sensitization to amphetamineinduced stereotypes can be blocked by intrastriatal infusions of nicotinic antagonists (Karler et al., 1996). By tonically controlling DA release in DA terminal fields, endogenous activation of terminal $\alpha 4 \beta 2^{\star}$ and $\alpha 6 \beta 2^{\star} \mathrm{nAChRs}$ is, thus, likely to modulate important aspects of natural and artificial reinforcement.

In summary (Fig. 6), in mouse DA neurons, heteromeric 


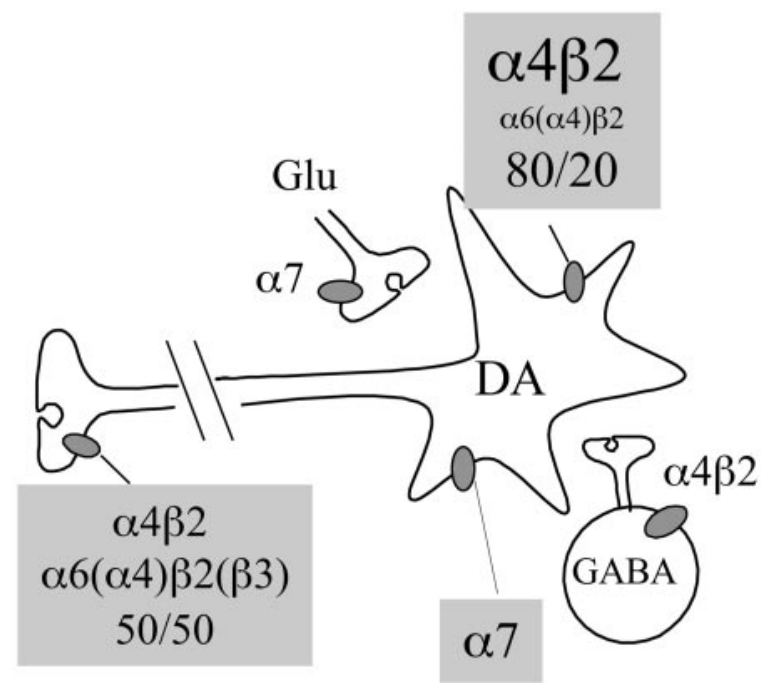

Figure 6. Subunit composition of functional $n A C h R s$ expressed by DA neurons. The relative proportion of the different $n A C h R$ subtypes mediating nicotine-induced DA release in striatal synaptosomes or ACh-elicited currents in SN/VTA are indicated (gray insets). The contribution of subunits in brackets to functional $\alpha 6^{*} \mathrm{nAChRs}$ remains to be fully established. In addition to its direct actions on $\mathrm{nAChRs} \mathrm{expressed} \mathrm{by} \mathrm{DA} \mathrm{neurons,} \mathrm{nicotine} \mathrm{might} \mathrm{increase} \mathrm{DA} \mathrm{concentration} \mathrm{in}$ the Nac by at least two other mechanisms. By acting on $\alpha 7 \mathrm{nAChRs}$ located on cortical glutamatergic terminals, nicotine stimulates intra-VTA glutamate release and alters the firing pattern of DA neurons via NMDA receptor activation (Nomikos et al., 2000). At concentrations close to those found in smokers' blood, nicotine desensitizes $\alpha 4 \beta 2$ nAChRs on GABAergic interneurons, thus relieving the inhibitory control they exert on DA neurons (Mansvelder et al., 2002). Both direct and indirect mechanisms are likely to play a role in nicotine reinforcement.

nAChRs contain the $\beta 2$ subunit associated with the $\alpha 4$ and/or the $\alpha 6$ subunits. On DA terminals, $\alpha 6 \beta 2^{*}$ and (non $\left.\alpha 6\right) \alpha 4 \beta 2^{*}$ nAChRs each contribute to $50 \%$ of nicotine effect on synaptosomal DA release. In contrast, (non $\alpha 6) \alpha 4 \beta 2^{\star}$ nAChRs mediate most of the slow ACh-elicited currents in the somato-dendritic compartment. Other evidence suggests that although $\alpha 6^{*}$ nAChRs are mainly located on DA nerve terminals, $\alpha 7^{\star}$ nAChRs are only present on DA neuronal soma. Whereas a critical contribution of somato-dendritic $\alpha 4 \beta 2^{\star}$ nAChRs to nicotine reinforcement is likely, the physiological role of $\alpha 4 \beta 2^{*}$ and $\alpha 6 \beta 2^{\star}$ nAChRs expressed on striatal DA terminals remains to be investigated further.

\section{References}

Berridge KC, Robinson TE (1998) What is the role of dopamine in reward: hedonic impact, reward learning, or incentive salience? Brain Res Rev 28:309-369.

Cartier GE, Yoshikami D, Gray WR, Luo S, Olivera BM, McIntosh JM (1996) A new $\alpha$-conotoxin which targets $\alpha 3 \beta 2$ nicotinic acetylcholine receptors. J Biol Chem 271:7522-7528.

Champtiaux N, Han ZY, Bessis A, Rossi FM, Zoli M, Marubio L, McIntosh JM, Changeux JP (2002) Distribution and pharmacology of $\alpha 6$ containing nicotinic acetylcholine receptors analyzed with mutant mice. J Neurosci 22:1208-1217.

Charpantier E, Barneoud P, Moser P, Besnard F, Sgard F (1998) Nicotinic acetylcholine subunit mRNA expression in dopaminergic neurons of the rat substantia nigra and ventral tegmental area. NeuroReport 9:3097-3101.

Clarke PB, Pert A (1985) Autoradiographic evidence for nicotine receptors on nigrostriatal and mesolimbic dopaminergic neurons. Brain Res 348:355-358.

Corrigall WA, Coen KM, Adamson KL (1994) Self-administered nicotine activates the mesolimbic dopamine system through the ventral tegmental area. Brain Res 653:278-284.

Corrigall WA, Coen KM, Zhang J, Adamson KL (2001) GABA mechanisms in the pedunculopontine tegmental nucleus influence particular aspects of nicotine self-administration selectively in the rat. Psychopharmacology (Berl) 158:190-197.

Di Chiara G (2000) Role of dopamine in the behavioural actions of nicotine related to addiction. Eur J Pharmacol 393:295-314.

Di Chiara G, Imperato A (1988) Drugs abused by humans preferentially increase synaptic dopamine concentrations in the mesolimbic system of freely moving rats. Proc Natl Acad Sci USA 85:5274-5278.

el-Bizri H, Clarke PB (1994) Blockade of nicotinic receptor-mediated release of dopamine from striatal synaptosomes by chlorisondamine and other nicotinic antagonists administered in vitro. Br J Pharmacol 111:406-413.

Gerdeman GL, Partridge JG, Lupica CR, Lovinger DM (2003) It could be habit forming: drugs of abuse and striatal synaptic plasticity. Trends Neurosci 26:184-192.

Grace AA, Onn SP (1989) Morphology and electrophysiological properties of immunocytochemically identified rat dopamine neurons recorded in vitro. J Neurosci 9:3463-3481.

Grady SR, Meinerz NM, Cao J, Reynolds AM, Picciotto MR, Changeux JP, McIntosh JM, Marks MJ, Collins AC (2001) Nicotinic agonists stimulate acetylcholine release from mouse interpeduncular nucleus: a function mediated by a different nAChR than dopamine release from striatum. J Neurochem 76:258-268.

Grady SR, Murphy KL, Cao J, Marks MJ, McIntosh JM, Collins AC (2002) Characterization of nicotinic agonist-induced $[(3) \mathrm{H}]$ dopamine release from synaptosomes prepared from four mouse brain regions. J Pharmacol Exp Ther 301:651-660.

Grenhoff J, Aston-Jones G, Svensson TH (1986) Nicotinic effects on the firing pattern of midbrain dopamine neurons. Acta Physiol Scand 128:351-358.

Groot-Kormelink PJ, Luyten WH, Colquhoun D, Sivilotti LG (1998) A reporter mutation approach shows incorporation of the "orphan" subunit beta3 into a functional nicotinic receptor. J Biol Chem 273:15317-15320.

Kaiser S, Wonnacott S (2000) $\alpha$-Bungarotoxin-sensitive nicotinic receptors indirectly modulate $[(3) \mathrm{H}]$ dopamine release in rat striatal slices via glutamate release. Mol Pharmacol 58:312-318.

Kaiser SA, Soliakov L, Harvey SC, Luetje CW, Wonnacott S (1998) Differential inhibition by $\alpha$-conotoxin-MII of the nicotinic stimulation of $[3 \mathrm{H}]$ dopamine release from rat striatal synaptosomes and slices. J Neurochem 70:1069-1076.

Karler R, Calder LD, Bedingfield JB (1996) A novel nicotinic-cholinergic role in behavioral sensitization to amphetamine-induced stereotypy in mice. Brain Res 725:192-198.

Kita T, Okamoto M, Nakashima T (1992) Nicotine-induced sensitization to ambulatory stimulant effect produced by daily administration into the ventral tegmental area and the nucleus accumbens in rats. Life Sci 50:583-590.

Klink R, de Kerchove d'Exaerde A, Zoli M, Changeux JP (2001) Molecular and physiological diversity of nicotinic acetylcholine receptors in the midbrain dopaminergic nuclei. J Neurosci 21:1452-1463.

Kulak JM, Nguyen TA, Olivera BM, McIntosh JM (1997) Alpha-conotoxin MII blocks nicotine-stimulated dopamine release in rat striatal synaptosomes. J Neurosci 17:5263-5270.

Kuryatov A, Olale F, Cooper J, Choi C, Lindstrom J (2000) Human $\alpha 6$ AChR subtypes: subunit composition, assembly, and pharmacological responses. Neuropharmacology 39:2570-2590.

Le Novère N, Zoli M, Changeux JP (1996) Neuronal nicotinic receptor $\alpha 6$ subunit mRNA is selectively concentrated in catecholaminergic nuclei of the rat brain. Eur J Neurosci 8:2428-2439.

Malagié I, Trillat AC, Bourin M, Jacquot C, Hen R, Gardier AM (2001) 5-HT1B autoreceptors limit the effects of selective serotonin re-uptake inhibitors in mouse hippocampus and frontal cortex. J Neurochem 76:865-871.

Mansvelder HD, Keath JR, McGehee DS (2002) Synaptic mechanisms underlie nicotine-induced excitability of brain reward areas. Neuron 33:905-919.

Marubio LM, del Mar Arroyo-Jimenez M, Cordero-Erausquin M, Lena C, Le Novere N, de Kerchove d'Exaerde A, Huchet M, Damaj MI, Changeux JP (1999) Reduced antinociception in mice lacking neuronal nicotinic receptor subunits. Nature 398:805-810.

Marubio LM, Gardier AM, Durier S, David D, Klink R, del Mar ArroyoJimenez M, McIntosh JM, Rossi FM, Champtiaux N, Zoli M, Changeux JP (2003) Effects of nicotine in the dopaminergic system of mice lacking the 
$\alpha 4$ subunit of neuronal nicotinic acetylcholine receptors. Eur J Neurosci 17:1329-1337.

Mogg AJ, Whiteaker P, McIntosh JM, Marks M, Collins AC, Wonnacott S (2002) Methyllycaconitine is a potent antagonist of $\alpha$-conotoxin-MIIsensitive presynaptic nicotinic acetylcholine receptors in rat striatum. J Pharmacol Exp Ther 302:197-204.

Nisell M, Nomikos GG, Svensson TH (1994) Systemic nicotine-induced dopamine release in the rat nucleus accumbens is regulated by nicotinic receptors in the ventral tegmental area. Synapse 16:36-44.

Nomikos GG, Schilstrom B, Hildebrand BE, Panagis G, Grenhoff J, Svensson TH (2000) Role of $\alpha 7$ nicotinic receptors in nicotine dependence and implications for psychiatric illness. Behav Brain Res 113:97-103.

Picciotto MR, Zoli M, Lena C, Bessis A, Lallemand Y, LeNovere N, Vincent P, Pich EM, Brulet P, Changeux JP (1995) Abnormal avoidance learning in mice lacking functional high-affinity nicotine receptor in the brain. Nature 374:65-67.

Picciotto MR, Zoli M, Rimondini R, Lena C, Marubio LM, Pich EM, Fuxe K, Changeux JP (1998) Acetylcholine receptors containing the $\beta 2$ subunit are involved in the reinforcing properties of nicotine. Nature 391:173-177.

Pidoplichko VI, DeBiasi M, Williams JT, Dani JA (1997) Nicotine activates and desensitizes midbrain dopamine neurons. Nature 390:401-404.

Ramirez-Latorre J, Yu CR, Qu X, Perin F, Karlin A, Role L (1996) Functional contributions of $\alpha 5$ subunit to neuronal acetylcholine receptor channels. Nature 380:347-351.

Role LW, Berg DK (1996) Nicotinic receptors in the development and modulation of CNS synapses. Neuron 16:1077-1085.
Sharples CG, Kaiser S, Soliakov L, Marks MJ, Collins AC, Washburn M, Wright E, Spencer JA, Gallagher T, Whiteaker P, Wonnacott S (2000) UB-165: a novel nicotinic agonist with subtype selectivity implicates the $\alpha 4 \beta 2^{\star}$ subtype in the modulation of dopamine release from rat striatal synaptosomes. J Neurosci 20:2783-2791.

Vailati S, Hanke W, Bejan A, Barabino B, Longhi R, Balestra B, Moretti M, Clementi F, Gotti C (1999) Functional alpha6-containing nicotinic receptors are present in chick retina. Mol Pharmacol 56:11-19.

Wang F, Gerzanich V, Wells GB, Anand R, Peng X, Keyser K, Lindstrom J (1996) Assembly of human neuronal nicotinic receptor $\alpha 5$ subunits with $\alpha 3, \beta 2$, and $\beta 4$ subunits. J Biol Chem 271:17656-17665.

Whiteaker P, Peterson CG, Xu W, McIntosh JM, Paylor R, Beaudet AL, Collins AC, Marks MJ (2002) Involvement of the alpha3 subunit in central nicotinic binding populations. J Neurosci 22:2522-2529.

Wooltorton JR, Pidoplichko VI, Broide RS, Dani JA (2003) Differential desensitization and distribution of nicotinic acetylcholine receptor subtypes in midbrain dopamine areas. J Neurosci 23:3176-3185.

Zachariou V, Caldarone BJ, Weathers-Lowin A, George TP, Elsworth JD, Roth RH, Changeux JP, Picciotto MR (2001) Nicotine receptor inactivation decreases sensitivity to cocaine. Neuropsychopharmacology 24:576-589.

Zhou FM, Liang Y, Dani JA (2001) Endogenous nicotinic cholinergic activity regulates dopamine release in the striatum. Nat Neurosci 4:1224-1229.

Zoli M, Moretti M, Zanardi A, McIntosh JM, Clementi F, Gotti C (2002) Identification of the nicotinic receptor subtypes expressed on dopaminergic terminals in the rat striatum. J Neurosci 22:8785-8789. 